\title{
Sistem E-Filing dan Kepatuhan Wajib Pajak Orang Pribadi: Studi D\&M IS Success Model pada KPP Pratama Denpasar Timur
}

\author{
I Gusti Agung Ayu Ngr. Garnetia Pramanita ${ }^{1}$ \\ Fakultas Ekonomi dan Bisnis \\ Universitas Udayana, Indonesia
}

\author{
Ni Ketut Rasmini ${ }^{2}$ \\ Fakultas Ekonomi dan Bisnis \\ Universitas Udayana, Indonesia
}

\begin{abstract}
Surel : gtiapram@gmail.com
ABSTRAK

Penelitian ini bertujuan menganalisa pengaruh kualitas informasi, kualitas sistem, kualitas layanan, penggunaan, dan kepuasan pengguna sistem e-filing terhadap kepatuhan wajib pajak orang pribadi. Penelitian ini dilakukan dengan menyebar kuesioner secara offline dan online kepada wajib pajak orang pribadi pengguna e-filing di KPP Pratama Denpasar Timur. Total sampel adalah 100 WPOP dengan memakai teknik convenience sampling. Teknik analisis data yang digunakan yaitu partial least square dengan aplikasi SmartPLS 3.2.8. Hasil penelitian ini menunjukkan bahwa kualitas informasi serta kualitas sistem berpengaruh positif pada penggunaan sistem e-filing. Kualitas informasi, kualitas sistem dan kualitas layanan berpengaruh terhadap kepuasan pengguna sistem e-filing, penggunaan dan kepuasan pengguna sistem e-filing berpengaruh positif terhadap kepatuhan wajib pajak. Hasil penelitian ini dapat dijadikan masukan oleh pemerintah dalam upaya meningkatkan penggunaan e-filing oleh wajib pajak orang pribadi.
\end{abstract}

Kata Kunci: E-filing; Updated D\&M IS Success Model; Kepatuhan Wajib Pajak.

\section{E-Filing System and Individual Taxpayer Compliance: Study DEM IS Success Model on KPP Pratama Denpasar Timur}

\begin{abstract}
This study aims to analyze the effect of information quality, system quality, service quality, use, and user satisfaction of e-filing systems on individual taxpayer compliance. This research was conducted by distributing questionnaires online and offline to e-filing individual taxpayers at KPP Pratama Timur Denpasar. The total sample is 100 individual taxpayers using convenience sampling techniques. The data analysis technique used is partial least square with SmartPLS 3.2.8 application. The results of this study indicate that information quality and system quality have a positive effect on the use of e-filing systems. Information quality, system quality and service quality influence the satisfaction of e-filing system users, the use and satisfaction of e-filing system users have a positive effect on taxpayer compliance. The results of this study can be used as input by the government in an effort to increase the use of e-filing by individual taxpayers.
\end{abstract}

Keywords: $\quad$ E-filing; Updated DEM IS Success Model; Taxpayer Compliance.

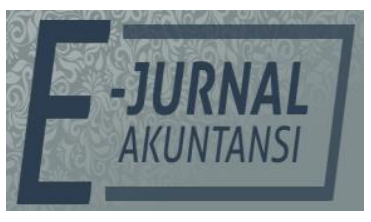

e-ISSN 2302-8556

Vol. 30 No. 11

Denpasar, Nopember 2020 Hal. 2825-2838

DOI:

10.24843/EJA.2020.v30.i11.p10

PENGUTIPAN:

Pramanita, I G.A.A.N.G. \&

Rasmini, N.K. (2020). Sistem

E-Filing dan Kepatuhan Wajib

Pajak Orang Pribadi: Studi

D\&M IS Success Model pada KPP Pratama Denpasar

Timur. E-Jurnal Akuntansi, 30(11), 2825-2838

\section{RIWAYAT ARTIKEL:}

Artikel Masuk:

11 Mei 2020

Artikel Diterima:

26 Juli 2020

Artikel dapat diakses : https://ojs.unud.ac.id/index.php/Akuntansi/index 


\section{PENDAHULUAN}

Pajak adalah kontribusi wajib kepada negara yang terutang oleh orang pribadi atau badan yang bersifat memaksa berdasarkan undang-undang, dengan tidak mendapatkan imbalan secara langsung dan digunakan untuk keperluan negara bagi sebesar-besarnya kemakmuran rakyat (UU No 16 tahun 2009). Pendapatan yang dimobilisasi dari pajak merupakan pendanaan utama untuk pengeluaran pemerintah (Kuug, 2015). Sebagai salah satu unsur penerimaan negara, pajak memiliki peran yang sangat besar dan semakin diandalkan untuk kepentingan pembangunan dan pengeluaran pemerintah. Reformasi perpajakan dilakukan pemerintah sebagai langkah awal untuk meningkatkan penerimaan dari sektor perpajakan secara menyeluruh dengan mengganti official assessment system menjadi self assessment system, self assessment system adalah sistem dimana wajib pajak diberi kepercayaan penuh untuk menghitung, membayar, dan melaporkan sendiri pajak yang terutang, dianutnya self assessment system membawa misi dan konsekuensi perubahan sikap (kesadaran) masyarakat untuk membayar pajak secara sukarela (Diamastuti, 2016).

Self assessment system diharapkan dapat menciptakan administrasi perpajakan yang rapi, terkendali, sederhana, dan mudah dipahami serta meningkatkan kepatuhan wajib pajak (Khulsum \& Satyawan, 2014). Kepatuhan wajib pajak telah menjadi perhatian utama bagi sebagian besar negara termasuk negara maju dan berkembang (Nuridayu et al., 2017). Kepatuhan wajib pajak merupakan pemenuhan kewajiban perpajakan yang dilakukan oleh pembayar pajak dalam rangka memberikan kontribusi bagi pembangunan negara secara sukarela dan menyampaikan surat pemberitahuan tahunannya dengan lengkap dan benar (Siahaan \& Halimatusyadiah, 2018). Realisasi pelaporan Surat Pemberitahuan (SPT) Tahunan yang dicatat Direktorat Jenderal Pajak mencapai 11,309 juta wajib pajak hingga 1 April 2019, persentase jumlah pelaporan itu setara $61,7 \%$ dari 18,334 juta wajib pajak yang seharusnya melaporkan kewajiban perpajakannya (economy.okezone.com).

Salah satu upaya pembaharuan yang dilakukan oleh Dirjen Pajak yaitu dengan mengadopsi dan mengintegrasikan teknologi informasi dalam administrasi perpajakan. Berdasarkan surat keputusan KEP-05/PJ./2005, Direktorat Jenderal Pajak mengeluarkan suatu pembaharuan mengenai Tata Cara Penyampaian SPT secara elektronik (e-filing) (Damayanti \& Fauzi, 2015). Efiling merupakan sarana yang disediakan pemerintah bagi wajib pajak untuk melaporkan pajaknya melalui internet pada website Direktorat Jenderal Pajak atau Penyedia Layanan SPT Elektronik atau Application Service Provider (ASP) secara online dan real time (www.kemenkeu.go.id).

Adanya penerapan sistem e-filing tidak mengakibatkan wajib pajak melaporkan SPT Tahunannya tepat waktu, masih ada yang terlambat untuk melaporkan kewajiban perpajakannya. Salah satu teori yang menjelaskan tentang model keberhasilan sistem informasi adalah updated DeLone and McLean IS Success Model. Updated D\&M IS Success Model adalah model keberhasilan sistem informasi yang dikembangkan oleh DeLone dan McLean pada tahun 1992 untuk mengukur kesuksesan atau keefektifan dari sistem informasi dan disempurnakan pada tahun 2003 dengan memasukkan ukuran kualitas layanan karena lonjakan dari penggunaan teknologi informasi (DeLone \& McLean, 2016). 
Updated D\&M IS Success Model terdiri dari kualitas sistem, kualitas informasi, kualitas layanan, penggunaan/minat untuk menggunakan, kepuasan pengguna, dan manfaat bersih.

Beberapa penelitian telah dilakukan dalam kaitannya dengan penerapan e-filing menggunakan Updated D\&M IS Success Model seperti Kara (2018) melakukan penelitian mengenai pengaruh penggunaan dan kepuasan pengguna e-filing terhadap kepatuhan pajak. Hasil penelitian menunjukkan kualitas informasi tidak berpengaruh terhadap penggunaan $e$-filing namun berpengaruh terhadap kepuasan pengguna. Kualitas sistem tidak berpengaruh terhadap penggunaan namun berpengaruh terhadap kepuasan pengguna. Kualitas layanan tidak berpengaruh terhadap penggunaan dan kepuasaan penggunaan. Pengunaan dan kepuasan penggunaan $e$-filing berpengaruh terhadap kepatuhan pajak. Utomo et al., (2019) melakukan penelitian mengenai pengaruh kualitas $e$ government terhadap kepuasan pengguna e-filing hasil analisis yang dilakukan menunjukkan bahwa ada pengaruh positif kualitas sistem dan kualitas layanan terhadap kepuasan pengguna e-filing, sedangkan kualitas informasi tidak berpengaruh terhadap kepuasan pengguna $e$-filing.

Kualitas informasi memiliki pengaruh terhadap penggunaan dan kepuasan pengguna, hal ini dikarenakan kualitas informasi mencakup informasiinformasi yang diperlukan dalam menggunakan e-filing khususnya dalam hal kelengkapan, kemudahan dalam memahaminya, dan kebermanfaatannya akan sangat mempengaruhi terhadap penggunaan dan kepuasan pengguna. Berdasarkan penelitian Ihsan \& Azwar (2018) dan Ningrum \& Andi (2016) menyatakan bahwa semakin tinggi kualitas informasi, semakin tinggi pula kepuasan pengguna dan penggunaan sebenarnya akan terjadi, sedangkan menurut Kara (2018) dan Utomo et al., (2019) kualitas informasi tidak berpengaruh terhadap niat dalam penggunaan dan kepuasan pengguna dari sistem $e$-filing.

Kualitas sistem memiliki pengaruh terhadap penggunaan dan kepuasan pengguna, hal ini dikarenakan dengan tingginya kualitas sistem yang disediakan dari suatu informasi akan mempengaruhi penggunaan dan kepuasan pengguna dari suatu sistem. Berdasarkan penelitian yang telah dilakukan, menurut Baikhuni (2018) serta Ningrum \& Andi (2016) menyatakan bahwa semakin tinggi kualitas informasi yang ditemukan pada sistem informasi, semakin tinggi pula penggunaan dan kepuasan pengguna dalam suatu sistem, sedangkan menurut Arista (2015) dan Zaidi et al., (2017) kualitas sistem tidak berpengaruh terhadap niat dalam penggunaan dan kepuasan pengguna dari sistem e-filing.

Kualitas layanan memiliki pengaruh terhadap penggunaan dan kepuasan pengguna, hal ini dikarenakan dengan kualitas layanan yang baik dari suatu sistem seperti tingkat keamanan dan tanggapan yang diberikan dari suatu sistem, akan meningkatkan penggunaan dan kepuasan pengguna dari suatu sistem. Menurut penelitian Sari \& Rachmanto (2018) dan Baikhuni (2018) menyatakan bahwa semakin tinggi kualitas layanan yang ditemukan pada sistem informasi, semakin tinggi pula penggunaan dan kepuasan pengguna dalam suatu sistem, sedangkan menurut Chen et al., (2015) dan Kara (2018) kualitas layanan tidak berpengaruh terhadap niat dalam penggunaan dan kepuasan pengguna dari sistem $e$-filing. 
Penggunaan suatu sistem berpengaruh terhadap manfaat bersih yang didapatkan, hal ini karena pengguna akan menggunakan suatu sistem jika dirasa sistem tersebut memberikan manfaat yang akan diterima oleh pengguna, sehingga semakin tinggi penggunaan maka manfaat yang diperoleh juga tinggi. Berdasarkan penelitian dari Ihsan \& Azwar (2018) menyatakan bahwa penggunaan berpengaruh terhadap manfaat bersih. Kepuasan pengguna memiliki pengaruh terhadap manfaat bersih, hal ini karena pengguna yang merasa puas terhadap suatu sistem, maka manfaat yang diperoleh juga akan semakin tinggi. Berdasarkan penelitian dari Wei et al., (2017) menyatakan bahwa kepuasan pengguna berpengaruh terhadap manfaat bersih.

Penelitian yang dilakukan oleh Ihsan \& Azwar (2018) mengenai analisis faktor yang mempengaruhi kesuksesan implementasi sistem e-filing di KPP Madya Makasar, dengan menggunakan enam variabel utama yaitu kualitas sistem, kualitas informasi, kepuasan pengguna, penggunaan sistem, dampak individual dan dampak organisasi. Ditunjukkan bahwa kualitas sistem dan kualitas informasi berpengaruh terhadap kepuasan pengguna, kualitas informasi berpengaruh terhadap penggunaan, penggunaan dan kepuasan pengguna berpengaruh terhadap dampak individu, serta dampak individu berpengaruh terhadap dampak organisasi pemakai sistem $e$-filing. Penelitian tersebut menjadi acuan untuk mengembangkan penelitian di KPP Pratama Denpasar Timur dengan menggunakan updated D\&M IS Success Model untuk menganalisis kesuksesan dari pengadopsian sistem e-filing. Selain itu pada penelitian ini, variabel manfaat bersih (net benefit) diturunkan menjadi variabel yang lebih khusus dalam kaitannya dengan sistem $e$-filing yaitu menjadi variabel kepatuhan wajib pajak. Penelitian ini juga untuk melakukan justifikasi dari hasil penelitian yang ditemukan belum konsisten oleh peneliti terdahulu. Berdasarkan fenomena yang ada dengan mengacu pada updated DeLone and McLean IS Success Model membuat penelitian mengenai sistem $e$-filing dan kepatuhan wajib pajak orang pribadi menarik untuk dilakukan.

Updated D\&M IS Success Model menunjukkan bahwa kualitas informasi, kualitas sistem, dan kualitas layanan mempengaruhi kepuasan pengguna dan niat untuk menggunakan/penggunaan aktual. Semakin tinggi kualitas informasi, kualitas sistem, dan kualitas layanan yang ditemukan pada sistem informasi, semakin tinggi kepuasan pengguna dan niat untuk menggunakan/penggunaan sebenarnya akan terjadi. Begitu pula dengan tingginya penggunaan sebenarnya dan kepuasan pengguna dari suatu sistem akan berpengaruh pada manfaat bersih yang tinggi (DeLone \& McLean, 2016).

Kepatuhan pajak adalah kemampuan wajib pajak untuk mematuhi undang-undang perpajakan, dimana wajib pajak menyatakan pendapatan yang benar di setiap tahun dan membayar jumlah pajak dengan tepat waktu (Oladipupo \& Obazee, 2016). Secara teoretis, kepatuhan pajak dapat didefinisikan dengan mempertimbangkan tiga jenis kepatuhan yang berbeda seperti kepatuhan pembayaran, kepatuhan pengajuan, dan kepatuhan pelaporan (Chebusit et al., 2014).

Pengguna akan semakin sering menggunakan sistem karena mengganggap sistem tersebut dapat diandalkan jika kualitas informasi/output yang dihasilkan oleh suatu sistem semakin baik. Penelitian yang dilakukan yang 
dilakukan oleh Ihsan \& Azwar (2018) menemukan bahwa kualitas informasi berpengaruh terhadap penggunaan sistem $e$-filing bagi wajib pajak badan di KPP Pratama Makasar. Penelitian ini didukung oleh penelitian yang dilakukan oleh Tam \& Oliveira (2016), Prameswara \& Wirasedana (2018) serta Rai \& Suardhika (2019) menunjukkan bahwa kualitas informasi berpengaruh pada kepuasan pengguna sistem. Berdasarkan hasil dari beberapa penelitian terdahulu serta teori yang ada, hipotesis yang dapat dikembangkan dalam penelitian ini yaitu: $\mathrm{H}_{1}$ : Kualitas informasi berpengaruh positif terhadap penggunaan sistem $e$-filing.

Updated DeLone and McLean IS success model menyatakan bahwa kualitas informasi berpengaruh positif terhadap kepuasan pengguna. Semakin baik kualitas informasi yang dihasilkan oleh sistem, maka akan semakin baik pula keputusan yang dapat diambil berdasarkan informasi tersebut. Penelitian oleh Ningrum \& Andi (2016) yang meneliti wajib pajak pengguna $e$-filing di KPP Pratama Serang, menemukan terdapat hubungan yang memengaruhi antara kualitas informasi dengan kepuasan pengguna. Hasil serupa juga ditemukan dalam penelitian yang dilakukan oleh Tam \& Oliveira (2016), Abadi et al., (2017), serta Solikah \& Kusumaningtyas (2017) menunjukkan bahwa kualitas informasi berpengaruh pada kepuasan pengguna sistem. Berdasarkan hasil dari beberapa penelitian terdahulu serta teori yang ada, hipotesis yang dapat dikembangkan dalam penelitian ini yaitu.

$\mathrm{H}_{2}$ : Kualitas informasi berpengaruh positif terhadap kepuasan pengguna sistem e-filing.

Semakin baik kualitas suatu sistem dalam mengolah data menjadi informasi yang tepat guna bagi pengguna, maka pengguna akan semakin sering menggunakan sistem tersebut karena dianggap akan membantu penyelesaian suatu tugas. Kualitas sistem $e$-filing yang mudah untuk digunakan, cepat handal dan fleksibel maka pengguna akan mengulangi menggunaan sistem e-filing tersebut dimasa yang akan datang. Penelitian Baikhuni (2018) menunjukkan kualitas sistem berpengaruh terhadap penggunaan sistem e-filing bagi pegawai Bank Jatim Kota Madiun. Penelitian ini didukung oleh penelitian Tam \& Oliveira (2016), Prameswara \& Wirasedana (2018) serta Rai \& Suardhika (2019) menunjukkan bahwa kualitas sistem berpengaruh pada penggunaan sistem. Berdasarkan hasil dari beberapa penelitian terdahulu serta teori yang ada, hipotesis yang dapat dikembangkan dalam penelitian ini yaitu.

$\mathrm{H}_{3}$ : Kualitas sistem berpengaruh positif terhadap penggunaan sistem $e$-filing.

Kualitas sistem akan mempengaruhi kepuasan penggunaan sistem $e$ filling. Jika kualitas sistem e-filling baik maka pengguna akan merasa nyaman menggunakan sistem e-filling tersebut sehingga berpotensi untuk menggunakan sistem e-filling dalam menyampaikan Surat Pemberitahuan (SPT). Hasil penelitian empiris Ningrum \& Andi (2016) menunjukkan adanya pengaruh antara kualitas sistem dengan wajib pajak pribadi pengguna sistem e-filing. Didukung penelitian yang dilakukan oleh Chiu et al., (2016), Hidayati et al., (2017) serta Veeramootoo et al., (2018) menunjukan bahwa kualitas sistem berpengaruh pada kepuasan pengguna. Berdasarkan hasil dari beberapa penelitian terdahulu serta teori yang ada, hipotesis yang dapat dikembangkan dalam penelitian ini yaitu. 
$\mathrm{H}_{4}$ : Kualitas sistem berpengaruh positif terhadap kepuasan pengguna sistem $e$ filing.

Pengguna akan merasa puas dalam menggunakan sistem apabila kualitas layanan yang diberikan oleh sistem baik, demikian pula dengan kondisi sebaliknya. Sebuah sistem pasti memiliki pelayanan yang berbeda-beda, untuk melihat kesuksesan suatu sistem, pengukuran tidak hanya melihat dari kualitas informasi yang dihasilkan dan kualitas sistem itu sendiri. Pengukuran kesuksesan tidak boleh hanya melihat "produk" dari sistem tetapi juga perlu melihat dari segi "layanan" yang diberikan karena pada dasarnya layanan dari suatu sistem merupakan satu kesatuan dengan sistem itu sendiri. Teori ini didukung oleh penelitian Baikhuni (2018), Trihandayani et al., (2018), dan Wulandari et al., (2019) dalam penelitiannya menunjukkan bahwa kualitas layanan yang dimiliki oleh suatu sistem berpengaruh pada penggunaan sistem. Berdasarkan hasil dari beberapa penelitian terdahulu serta teori yang ada, hipotesis yang dapat dikembangkan dalam penelitian ini yaitu:

$\mathrm{H}_{5}$ : Kualitas layanan berpengaruh positif terhadap penggunaan sistem $e-f i l i n g$.

Sari dan Rachmanto (2018) dalam penelitiannya di KPP Pratama Garut, menemukan bahwa kualitas layanan berpengaruh pada kepuasan pengguna. Penelitian ini didukung oleh penelitian yang dilakukan Irfan (2019), Chiu et al., (2016), Tam \& Oliveira (2016) serta Utomo et al. (2019) menunjukkan bahwa kualitas layanan berpengaruh pada kepuasan pengguna. Berarti semakin tinggi kualitas layanan sistem maka pengguna juga akan semakin puas. Berdasarkan hasil dari beberapa penelitian terdahulu serta teori yang ada, hipotesis yang dapat dikembangkan dalam penelitian ini yaitu:

$\mathrm{H}_{6}$ : Kualitas layanan berpengaruh positif pada kepuasan pengguna sistem $e$ filing.

Sistem e-filing membantu para wajib pajak untuk menyediakan fasilitas pelaporan SPT secara elektronik (melalui internet) kepada wajib pajak, sehingga dapat dilakukan dari rumah atau tempatnya bekerja. Hal ini akan dapat membantu memangkas waktu dan biaya untuk mempersiapkan, memproses dan melaporkan SPT ke Kantor Pajak secara tepat waktu dan benar. Penelitian ini didukung oleh penelitian yang dilakukan Hudin \& Riana (2016) serta Wicaksono (2016) menunjukkan bahwa penggunaan berpengaruh pada kepuasan pengguna. Berdasarkan hasil dari beberapa penelitian terdahulu serta teori yang ada, hipotesis yang dapat dikembangkan dalam penelitian ini yaitu:

$\mathrm{H}_{7}$ : Penggunaan sistem $e$-filing berpengaruh terhadap kepuasan pengguna sistem e-filing.

Intensitas penggunaan sistem berpengaruh secara signifikan terhadap manfaat-manfaat bersih. Semakin sering pengguna memakai sistem informasi, biasanya diikuti oleh semakin banyak tingkat pembelajaran yang diperoleh pengguna dari sistem informasi. Teori ini didukung oleh penelitian (Trihandayani et al., 2018) dan (Noviyanti (2016). Manfaat bersih dalam penelitian ini yaitu variabel kepatuhan pajak (tax compliance). Berdasarkan hasil dari beberapa penelitian terdahulu serta teori yang ada, hipotesis yang dapat dikembangkan dalam penelitian ini yaitu:

$\mathrm{H}_{8}$ : Penggunaan sistem e-filing berpengaruh positif terhadap kepatuhan wajib pajak. 
Updated DeLone and McLean IS success model menunjukkan bahwa kepuasan pengguna yang lebih tinggi menghasilkan penggunaan aktual yang lebih tinggi pula. Dalam hal ini semakin puas pengguna terhadap suatu sistem, semakin sering pengguna akan menggunakan sistem tersebut secara berkelanjutan. Teori ini diperkuat kembali oleh penelitian yang dilakukan (Chiu et al., 2016). Manfaat bersih dalam penelitian ini merupakan variabel kepatuhan pajak. Hipotesis yang dirumuskan adalah sebagai berikut:

$\mathrm{H}_{9}$ : Kepuasan pengguna sistem $e$-filing berpengaruh positif terhadap kepatuhan wajib pajak.

\section{METODE PENELITIAN}

Penelitian ini menggunakan pendekatan kuantitatif berbentuk asosiatif yang dilaksanakan di KPP Pratama Denpasar Timur. Obyek penelitian ini adalah kualitas informasi, kualitas sistem, kualitas layanan, penggunaan sistem, kepuasan pengguna, serta kepatuhan wajib pajak. Populasi dalam penelitian ini adalah seluruh wajib pajak orang pribadi yang menggunakan e-filing dan terdaftar di KPP Pratama Denpasar Timur. Penentuan sampel dengan metode nonprobability sampling, teknik convenience sampling. Metode pengumpulan data dalam penelitian ini dilakukan dengan teknik kuesioner. Data dikumpulkan dari para responden menggunakan kuisioner dengan skala likert modifikasi yaitu jawaban responden akan diberi nilai dengan skala 4 poin sebagai skor tertinggi dan skala 1 poin untuk skala terendah. Analisis data dengan menggunakan Uji Partial Least Square (PLS).

\section{HASIL DAN PEMBAHASAN}

Waktu penyebaran kuesioner dimulai pada tanggal 29 Januari 2020 sampai tanggal 14 Februari 2020. Kuesioner yang disebarkan sebanyak 100 kuesioner dengan tingkat pengembalian responden (responden rate) sebesar 100 persen dan tingkat pengembalian yang dapat dianalisis (unseable responden rate) sebesar 100 persen. Hasil statistik deskriptif dalam penelitian ini dapat dilihat pada Tabel 1, berikut.

\section{Tabel 1. Hasil Statistik Deskriptif}

\begin{tabular}{llrrrr}
\hline & $\mathrm{N}$ & Minimum & Maximum & Mean & Std. Deviation \\
\hline Kualitas Informasi $\left(\mathrm{X}_{1}\right)$ & 100 & 2,00 & 4,00 & 3,373 & 0,628 \\
Kualitas Sistem $\left(\mathrm{X}_{2}\right)$ & 100 & 2,00 & 4,00 & 3,448 & 0,677 \\
Kualitas Layanan $\left(\mathrm{X}_{3}\right)$ & 100 & 2,00 & 4,00 & 3,419 & 0,687 \\
Penggunaan Sistem $\left(\mathrm{X}_{4}\right)$ & 100 & 2,00 & 4,00 & 3,423 & 0,678 \\
Kepuasan Pengguna $\left(\mathrm{X}_{5}\right)$ & 100 & 2,00 & 4,00 & 3,388 & 0,652 \\
Kepatuhan Wajib Pajak $(\mathrm{Y})$ & 100 & 2,00 & 4,00 & 3,350 & 0,544 \\
Valid N (listwise) & 100 & & & &
\end{tabular}

Sumber: Data Penelitian, 2020

Hasil statistik deskriptif di atas menampilkan variabel kualitas informasi mempunyai nilai minimum sebesar 2,00, nilai maksimum sebesar 4,00, nilai ratarata sebesar 3,373. Nilai rata-rata tersebut memiliki kecenderungan mendekati nilai maksimum yang artinya responden cenderung menyetujui pernyataan terkait kualitas informasi. Variabel kualitas informasi memiliki nilai standar 
deviasi yang kecil yaitu sebesar 0,628. Hal ini menunjukkan bahwa data penelitian bersifat homogen sehingga dapat dikatakan bahwa wajib pajak memiliki persepsi bahwa kualitas informasi yang disajikan sistem $e$-filing baik.

Variabel kualitas sistem mempunyai nilai minimum sebesar 2,00, nilai maksimum sebesar 4,00, nilai rata-rata sebesar 3,448. Nilai rata-rata tersebut memiliki kecenderungan mendekati nilai maksimum yang artinya responden cenderung menyetujui pernyataan terkait kualitas sistem. Variabel kualitas sistem memiliki nilai standar deviasi yang kecil yaitu sebesar 0,677 . Hal ini berarti data penelitian bersifat homogen sehingga dapat dikatakan bahwa wajib pajak memiliki persepsi bahwa kualitas sistem yang disajikan sistem $e$-filing baik.

Variabel kualitas layanan mempunyai nilai minimum sebesar 2,00 dan nilai maksimum sebesar 4,00, nilai rata-rata sebesar 3,419. Nilai rata-rata tersebut memiliki kecenderungan mendekati nilai maksimum yang artinya responden cenderung menyetujui pernyataan terkait kualitas layanan. Variabel kualitas layanan memiliki nilai standar deviasi yang kecil sebesar 0,687. Hal ini berarti data penelitian bersifat homogen sehingga dapat dikatakan bahwa wajib pajak memiliki persepsi bahwa kualitas layanan yang disajikan sistem $e$-filing baik.

Variabel penggunaan sistem mempunyai nilai minimum sebesar 2,00, nilai maksimum sebesar 4,00, nilai rata-rata sebesar 3,423. Nilai rata-rata tersebut memiliki kecenderungan mendekati nilai maksimum yang artinya responden cenderung menyetujui pernyataan terkait penggunaan sistem. Variabel penggunaan sistem memiliki nilai standar deviasi yang kecil sebesar 0,678. Hal ini berarti data penelitian bersifat homogen sehingga dapat dikatakan penggunaan sistem $e$-filing tergolong tinggi.

Variabel kepuasan pengguna mempunyai nilai minimum sebesar 2,00, nilai maksimum sebesar 4,00, nilai rata-rata sebesar 3,388. Nilai rata-rata tersebut memiliki kecenderungan mendekati nilai maksimum yang artinya responden cenderung menyetujui pernyataan terkait kepuasan pengguna. Variabel kepuasan pengguna memiliki nilai standar deviasi yang kecil sebesar 0,652. Hal ini berarti data penelitian bersifat homogen sehingga dapat dikatakan pengguna sistem $e$-filing merasa puas dalam menggunakan sistem $e$-filing.

Variabel kepatuhan wajib pajak mempunyai nilai minimum sebesar 2,00, nilai maksimum sebesar 4,00, nilai rata-rata sebesar 3,350. Nilai rata-rata tersebut memiliki kecenderungan mendekati nilai maksimum yang artinya responden cenderung menyetujui pernyataan terkait kepatuhan wajib pajak. Variabel kepatuhan wajib pajak memiliki nilai standar deviasi yang kecil sebesar 0,544. Hal ini berarti data penelitian bersifat homogen sehingga dapat dikatakan kepatuhan wajib pajak tergolong baik.

Evaluasi model struktural atau inner model dievaluasi dengan menggunakan kalkukasi bootsrapping. Pengujian inner model meliputi goodness of fit $\left(\mathrm{R}^{2}\right)$ dan predictive relevance. Tabel nilai $R$-square variabel laten endogen disajikan pada Tabel 2.

Berdasarkan Tabel 2. nilai R-square variabel kepatuhan wajib pajak sebesar 0,628 yang dapat diinterpretasikan bahwa variabilitas variabel kepatuhan wajib pajak dapat dijelaskan oleh variabilitas variabel kualitas informasi, kualitas sistem, kualitas layanan, penggunaan dan kepuasan pengguna sebesar 62,8 
persen, sedangkan sisanya sebesar 37,2 persen dijelaskan oleh variabel lain di luar yang diteliti.

Tabel 2. Nilai $R$-square $\left(\mathbf{R}^{2}\right)$

\begin{tabular}{lc}
\hline Variabel Laten & R-square \\
\hline Penggunaan $\left(\mathrm{X}_{4}\right)$ & 0,680 \\
Kepuasan pengguna $\left(\mathrm{X}_{5}\right)$ & 0,826 \\
Kepatuhan wajib pajak $(\mathrm{Y})$ & 0,628 \\
\hline
\end{tabular}

Sumber: Data Penelitian, 2020

$Q$-square digunakan untuk mengukur seberapa baik nilai observasi dihasilkan oleh model dan juga estimasi parameternya. Nilai Q-square memiliki rentang nilai $0<Q^{2}<1$, dimana nilai $Q$-square yang semakin mendekati 1 berarti model semakin baik. Perhitungan Q-square yaitu.

$$
\mathrm{Q}^{2}=1-(1-0,680)(1-0,826)(1-0,628)
$$

Hasil perhitungan menggunakan rumus, didapat hasil $\mathrm{Q}^{2}$ sebesar 0,979, yang berarti bahwa model memiliki predictive relevance yang sangat baik. Berdasarkan perhitungan tersebut, maka dapat dijelaskan bahwa 97,9 persen variasi pada kepatuhan wajib pajak dipengaruhi oleh kualitas informasi, kualitas sistem, kualitas layanan, penggunaan dan kepuasan pengguna, sedangkan sisanya sebesar 2,1 persen dipengaruhi oleh variabel lain. Hasil uji pengaruh langsung masing-masing variabel dapat dilihat pada Tabel 3.

Tabel 3 Hasil Uji Pengaruh Langsung (Total Effect)

\begin{tabular}{|c|c|c|c|c|}
\hline Variabel & $\begin{array}{l}\text { Original } \\
\text { Sample }(O)\end{array}$ & $\begin{array}{l}T \\
\text { Statistics }\end{array}$ & $\begin{array}{l}P \\
\text { Values }\end{array}$ & Keterangan \\
\hline $\begin{array}{l}\text { Kualitas } \quad \text { Informasi } \\
>\text { Penggunaan }\end{array}$ & 0,423 & 3,637 & 0,000 & $\begin{array}{l}\text { Signifikan } \\
\text { Diterima }\end{array}$ \\
\hline $\begin{array}{l}\text { Kualitas } \quad \text { Infromasi } \\
>\text { Kepuasan Pengguna }\end{array}$ & 0,242 & 2,391 & 0,017 & $\begin{array}{l}\text { Signifikan } \\
\text { Diterima }\end{array}$ \\
\hline 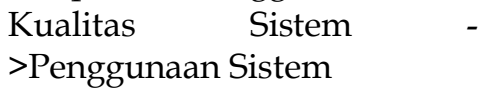 & 0,312 & 2,636 & 0,009 & $\begin{array}{l}\text { Signifikan } \\
\text { Diterima }\end{array}$ \\
\hline $\begin{array}{l}\text { Kualitas Sistem ->Kepuasan } \\
\text { Pengguna }\end{array}$ & 0,283 & 3,312 & 0,001 & ikan \\
\hline $\begin{array}{ll}\text { Kualitas } & \text { Layanan } \\
>\text { Penggunaan } & \text { Sistem }\end{array}$ & 0,190 & 1,713 & 0,087 & $\begin{array}{l}\text { Signifikan } \\
\text { lak }\end{array}$ \\
\hline $\begin{array}{l}\text { Kualitas Layanan ->Kepuasan } \\
\text { Pengguna }\end{array}$ & 0,494 & 4,925 & 0,000 & $\begin{array}{l}\text { Signi } \\
\text { Diter }\end{array}$ \\
\hline $\begin{array}{l}\text { Penggunaan Sistem-> } \\
\text { Kepuasan Pengguna }\end{array}$ & 0,102 & 1,226 & 0,221 & $\begin{array}{l}\text { Signifikan } \\
\text { lak }\end{array}$ \\
\hline $\begin{array}{l}\text { Penggunaan Sistem } \\
\text { >Kepatuhan Wajib Pajak }\end{array}$ & 0,401 & 3,585 & 0,000 & $\begin{array}{l}\text { Signifikan } \\
\text { Diterima }\end{array}$ \\
\hline $\begin{array}{l}\text { Kepuasan Pengguna } \\
>\text { >Kepatuhan Wajib Pajak }\end{array}$ & 0,492 & 4,480 & 0,000 & $\begin{array}{l}\text { Signifikan } \\
\text { Diterima }\end{array}$ \\
\hline
\end{tabular}

Sumber: Data Penelitian, 2020

Tabel 3. menjelaskan bahwa hasil pengujian kualitas informasi terhadap penggunaan sistem memiliki pengaruh langsung dengan nilai kofisien sebesar 0,423 dengan nilai $t$-statistik 3,637> t-tabel 1,96 dan $p$ value sebesar 0,000 < 0,05. Hal ini menunjukkan bahwa kualitas informasi memiliki pengaruh positif terhadap penggunaan sistem e-filing, oleh karena itu, $\mathrm{H}_{1}$ diterima. Hasil penelitian ini sejalan dengan penelitian yang dilakukan oleh Ihsan \& Azwar 
(2018) menemukan bahwa kualitas informasi berpengaruh terhadap penggunaan sistem e-filing bagi wajib pajak badan di KPP Pratama Makasar.

Hasil pengujian kualitas informasi terhadap kepuasan pengguna sistem $e$ filing memiliki pengaruh langsung dengan nilai kofisien sebesar 0,242 dengan nilai t-statistik sebesar 2,391 > t-tabel 1,96 dan nilai $\mathrm{p}$ value sebesar 0,017 < 0,05. Hal ini menunjukkan bahwa kualitas informasi memiliki pengaruh positif terhadap penggunaan sistem e-filing, oleh karena itu, $\mathrm{H}_{2}$ diterima. Hasil penelitian ini sejalan dengan penelitian oleh Ningrum \& Andi (2016), Chumsombat (2015) serta Nurhayati \& Kusmuriyanto (2017) juga memperoleh hasil kualitas informasi berpengaruh terhadap kepuasan pengguna.

Hasil pengujian kualitas sistem terhadap penggunaan sistem e-filing memiliki pengaruh langsung dengan nilai kofisien sebesar 0,312 dengan nilai tstatistik sebesar 2,636 > t-tabel 1,96 dan nilai $\mathrm{p}$ value $0,009<0,05$. Hal ini menunjukkan bahwa kualitas sistem memiliki pengaruh positif terhadap penggunaan sistem e-filing, oleh karena itu, $\mathrm{H}_{3}$ diterima. Hasil penelitian ini sejalan dengan penelitian yang dilakukan oleh Baikhuni (2018) menunjukkan kualitas sistem berpengaruh terhadap penggunaan sistem $e$-filing bagi pegawai Bank Jatim Kota Madiun.

Hasil pengujian kualitas sistem terhadap kepuasan pengguna sistem $e$ filing memiliki pengaruh langsung dengan nilai kofisien sebesar 0,283 dengan nilai t-statistik sebesar 3,312 > t-tabel 1,96 dan nilai $\mathrm{p}$ value sebesar 0,001 < 0,05. Hal ini menunjukkan bahwa kualitas sistem memiliki pengaruh positif terhadap kepuasan pengguna sistem e-filing, oleh karena itu, $\mathrm{H}_{4}$ diterima. Hasil penelitian ini sejalan dengan penelitian oleh Ningrum \& Andi (2016) yang meneliti wajib pajak pengguna e-filing di KPP Pratama Serang, menemukan terdapat hubungan yang memengaruhi antara kualitas informasi dengan kepuasan pengguna. Penelitian Hidayati et al., (2017) dan Veeramootoo et al. (2018) juga memperoleh hasil kualitas sistem berpengaruh terhadap kepuasan pengguna sistem.

Hasil pengujian kualitas layanan terhadap penggunaan sistem e-filing memiliki pengaruh langsung dengan nilai kofisien sebesar 0,19 dengan nilai $t-$ statistik sebesar 1,713 < t-tabel 1,96 dan nilai $\mathrm{p}$ value sebesar $0,087>0,05$. Hal ini menunjukkan bahwa kualitas layanan tidak memiliki pengaruh positif terhadap penggunaan sistem $e$-filing, dikarenakan $\mathrm{t}$-statistik lebih kecil dibandingkan $\mathrm{t}$ tabel dan $\mathrm{p}$ value lebih besar dari yang ditetapkan 5 persen. Oleh karena itu, $\mathrm{H}_{5}$ ditolak. Hasil pengujian ini sesuai dengan penelitian yang dilakukan oleh Prameswara \& Wirasedana (2018), serta Rai \& Suardikha (2019) yang menyatakan bahwa kualitas layanan dari suatu sistem tidak berpengaruh terhadap penggunaan dari suatu sistem.

Hasil pengujian kualitas layanan terhadap kepuasan pengguna sistem $e$ filing memiliki pengaruh langsung dengan nilai kofisien sebesar 0,494 dengan nilai t-statistik sebesar 4,925 > t-tabel 1,96 dan nilai $\mathrm{p}$ value sebesar 0,000 < 0,05. Hal ini menunjukkan bahwa kualitas layanan memiliki pengaruh positif kepuasan pengguna sistem e-filing, oleh karena itu, $\mathrm{H}_{6}$ diterima. Hasil penelitian ini sejalan dengan penelitian yang dilakukan oleh Sari \& Rachmanto (2018) dalam penelitiannya di KPP Pratama Garut, menemukan bahwa kualitas layanan berpengaruh pada kepuasan pengguna. 
Hasil pengujian penggunaan sistem terhadap kepuasan pengguna sistem e-filing memiliki pengaruh langsung dengan nilai kofisien sebesar 0,102 dengan nilai t-statistik sebesar 1,226 < t-tabel 1,96 dan nilai $\mathrm{p}$ value sebesar 0,221 > 0,05. Hal ini menunjukkan bahwa penggunaan sistem tidak memiliki pengaruh positif terhadap kepuasan pengguna sistem $e$-filing, dikarenakan t-statistik lebih kecil dibandingkan $t$-tabel dan $\mathrm{p}$ value lebih besar dari yang ditetapkan 5 persen. Oleh karena itu, $\mathrm{H}_{7}$ ditolak. Hasil penelitian serupa diperoleh dalam penelitian yang dilakukan oleh Ihsan \& Azwar (2018) penelitian tersebut menemukan bahwa penggunaan sistem tidak memengaruhi kepuasan pengguna. Penelitian Azazi (2016) dan Noviyanti (2016) juga memperoleh hasil yang sama yaitu penggunaan sistem tidak mempengaruhi kepuasan pengguna.

Hasil pengujian penggunaan sistem $e$-filing terhadap kepatuhan wajib pajak memiliki pengaruh langsung dengan nilai kofisien sebesar 0,401 dengan nilai $\mathrm{t}$-statistik sebesar 3,585 > t-tabel 1,96 dan nilai $\mathrm{p}$ value sebesar $0,000<0,05$. Hal ini menunjukkan bahwa penggunaan sistem memiliki pengaruh positif terhadap kepatuhan wajib pajak, oleh karena itu, $\mathrm{H}_{8}$ diterima. Hasil ini sesuai dengan penelitian dari Kara (2018) terhadap wajib pajak orang pribadi pengguna $e$-filing di Daerah Istimewa Yogyakarta yang menyatakan penggunaan sistem $e$ filing berpengaruh positif terhadap kepatuhan wajib pajak.

Hasil pengujian kepuasan pengguna sistem e-filing terhadap kepatuhan wajib pajak memiliki pengaruh langsung dengan nilai kofisien sebesar 0,492 dengan nilai t-statistik 4,480 > t-tabel 1,96 dan nilai $\mathrm{p}$ value sebesar 0,000 0,05. Hal ini menunjukkan bahwa kepuasan pengguna memiliki pengaruh positif terhadap kepatuhan wajib pajak, oleh karena itu, $\mathrm{H}_{9}$ diterima. Hasil ini sesuai dengan penelitian dari Kara (2018) yang menyatakan kepuasan pengguna sistem e-filing berpengaruh positif terhadap kepatuhan wajib pajak.

Uji pengaruh tidak langsung juga dilakukan untuk mengetahui pengaruh kualitas informasi, kualitas sistem, kualitas layanan terhadap kepatuhan wajib pajak. Hasil uji pengaruh tidak langsung dapat dilihat pada Tabel 4.

Tabel 4. Hasil Uji Pengaruh Tidak Langsung

\begin{tabular}{|c|c|c|c|c|c|}
\hline Variabel & & $\begin{array}{l}\text { Original } \\
\text { Sample }\end{array}$ & $\begin{array}{l}\text { T } \\
\text { Statistict }\end{array}$ & $\begin{array}{l}P \\
\text { Values }\end{array}$ & Keterangan \\
\hline $\begin{array}{l}\text { Kualitas Informasi } \\
\text { Wajib Pajak }\end{array}$ & ->Kepatuhan & 0,268 & 3,751 & 0,000 & Signifikan \\
\hline $\begin{array}{l}\text { Kualitas Sistem } \\
\text { Wajib Pajak }\end{array}$ & ->Kepatuhan & 0,249 & 3,893 & 0,000 & Signifikan \\
\hline $\begin{array}{l}\text { Kualitas Layanan } \\
\text { Wajib Pajak }\end{array}$ & ->Kepatuhan & 0,310 & 3,965 & 0,000 & Signifikan \\
\hline
\end{tabular}

Sumber: Data Penelitian, 2020

Tabel 4. menjelaskan bahwa kualitas informasi memiliki pengaruh tidak langsung dengan nilai keofisien sebesar 0,268 terhadap kepatuhan wajib pajak dengan nilai t-statistik tidak langsung sebesar 3,751 $>$ t-tabel 1,96 dan taraf signifikansi $\mathrm{p}$ value $0,000<0,05$. Hal ini menunjukkan bahwa kualitas informasi memiliki pengaruh tidak langsung atau melalui perantara yang positif dan signifikan terhadap kepatuhan wajib pajak. Kualitas sistem memiliki pengaruh tidak langsung dengan nilai keofisien sebesar 0,249 terhadap kepatuhan wajib pajak dengan nilai t-statistik tidak langsung sebesar 3,893 > t-tabel 1,96 dan taraf 
signifikansi $\mathrm{p}$ value 0,000 < 0,05. Hal ini menunjukkan bahwa kualitas sistem memiliki pengaruh tidak langsung atau melalui perantara yang positif dan signifikan terhadap kepatuhan wajib pajak. Kualitas layanan memiliki pengaruh tidak langsung dengan nilai keofisien sebesar 0,310 terhadap kepatuhan wajib pajak dengan nilai t-statistik tidak langsung sebesar 3,965 $>\mathrm{t}$-tabel 1,96 dan taraf signifikansi $\mathrm{p}$ value $0,000<0,05$. Hal ini menunjukkan bahwa kualitas layanan memiliki pengaruh tidak langsung atau melalui perantara yang positif dan signifikan terhadap kepatuhan wajib pajak.

\section{SIMPULAN}

Berdasarkan hasil pengujian dapat disimpulkan bahwa kualitas informasi dan kualitas sistem berpengaruh terhadap penggunaan sistem e-filing. Kualitas informasi, kualitas sistem dan kualitas layanan berpengaruh terhadap kepuasan pengguna sistem e-filing. Pengunaan dan kepuasan pengguna sistem e-filing berpengaruh terhadap kepatuhan wajib pajak orang pribadi di KPP Pratama Denpasar Timur. Saran dari penelitian ini adalah diharapkan Direktorat Jenderal Pajak membuat sistem e-filing yang semakin mudah digunakan, memberikan jaminan rasa aman bagi pengguna, menambah kapasitas server sehingga apabila mendekati tanggal batas pelaporan server tidak mengalami gangguan atau server down.

\section{REFERENSI}

Abadi, A. M., Abadi, A. M., \& Jafari, A. (2017). Innovation Acceptance and Customer Satisfaction. A Survey On Tax Information Systems. AD-Minister, 30(1), 149-171.

Arista, D. (2015). Kualitas sistem dan kualitas informasi berpengaruh terhadap kepuasan pengguna e-filing dengan Implikasinya Pada Kinerja Individu. Jurnal Akuntansi Fakultas Ekonomi Dan Bisnis Universitas Komputer Indonesia, $1-17$.

Azazi, A. (2016). Uji Empiris Model Kesuksesan Sistem Informasi Pengelolaan Keuangan Daerah (SIPKD) di Pemerintah Kota Bukittinggi dengan menggunakan Delone MCLean Informatin System Success Model. Jurnal Akuntansi Fakultas Ekonomi Universitas Andalas.

Baikhuni, J. E. (2018). Pengaruh Kualitas Layanan Dan Kualitas Sistem Terhadap Minat Penggunaan E-Filing Dengan Persepsi Kemudahan Penggunaan Sebagai Variabel Intervening. Skripsi. Universitas Islam Indonesia

Chebusit, C., Namusonge, G. S., Biraori, O. E., \& Kipkoech, E. C. (2014). Factors Affecting Tax Compliance Among Small and Medium Enterprises in Kitale. International Journal of Recent Research in Commerce Economics and Management (IJRRCEM), 1(3), 60-75.

Chen, J. V., Jubilado, R. J. M., Capistrano, E. P. S., \& Yen, D. C. (2015). Factors Affecting Online Tax Filing - An Application Of The IS Success Model and Trust Theory. Computers in Human Behavior, 43, 251-262.

Chiu, P. S., Chao, I. C., Kao, C. C., Pu, Y. H., \& Huang, Y. M. (2016). Implementation and Evaluation Of Mobile E-Books In A Cloud Bookcase Using The Information System Success Model. Library Hi Tech, 34(2), 207223. 
Chumsombat, N. (2015). E-government Service the Case of E-tax filing in Thailand. International Conference on Information Networking, 451-455.

Damayanti, F., \& Fauzi, A. (2015). Pengaruh Fasilitas Drop Box , E-Spt Dan EFiling Dalam Penyampaian Surat Pemberitahuan (SPT) terhadap Kepuasan Wajib Pajak. Jurnal Akuntabilitas, VIII(3), 225-237.

DeLone, W. H., \& McLean, E. R. (2016). Information Systems Success Measurement. Foundations and Trends ${ }^{\circledR}$ in Information Systems, 2(1), 1-116.

Diamastuti, E. (2016). Ke(tidak)patuhan Wajib Pajak:Potret Self Assessment. Ekonomi Dan Keuangan, 20(80), 280-304.

Dwi Ningrum, D., \& Andi. (2016). Kulitas Sistem, Kualitas Informasi, Ketepatan Waktu, Kerahasiaan Dan Kepuasan Wajib Pajak Pengguna E-Filing. Tirtayasa Ekonomika, 11(2), 169-184.

Hidayati, N., Harimurti, F., \& Dewi. (2017). Analisis Pengaruh Kualitas Informasi Dan Kualitas Sistem Terhadap Kepuasan Pengguna Sistem E-Filing. Jurnal Riset Akuntansi Dan Keuangan Indonesia, 2(2), 55-61.

Hudin, J. M., \& Riana, D. (2016). Kajian Keberhasilan Penggunaan Sistem Informasi Accurate dengan Menggunakan Model Kesuksesan Sistem Informasi Delon dan McLean. Journal of Information Systems, 2(12), 56-62.

Ihsan, M., \& Azwar. (2018).Analisis Faktor-Faktor yang Memengaruhi Kesuksesan Implementasi Sistem E-Filing. Jurnal BPPK, 11(2), 12-34.

Indonesia, K. K. R. (2019). Penyampaian SPT Online. Retrieved from https://www.kemenkeu.go.id/page/penyampaian-spt-online/\%0ASistem

Irfan, M. (2019). Pengaruh Kualitas Sistem, Kualitas Informasi, dan Kualitas Pelayanan terhadap Net Benefits Pemakaian Sistem Pembayaran Briva dengan Variabel Intervening Kepuasan Pengguna (Validasi Model Kesuksesan Sistem Informasi Delone dan Mclean. Tesis. Universitas Islam Indonesia.

Kara, R. N. (2018). Pengaruh Penggunaan dan Kepuasan Pengguna E-Filing Terhadap Kepatuhan Pajak. Skripsi Fakultas Ekonomi Universitas Islam Indonesia.

Kementerian Keuangan Republik Indonesia. Undang-Undang Nomor 16 Tahun 2009 tentang Ketentuan Umum dan Tata Cara Perpajakan. (2009). Indonesia

Khulsum, U. A., \& Satyawan, M. D. (2014). Pengaruh Karakteristik Usaha Wajib Pajak Badan Terhadap Tingkat Kepatuhan Berdasarkan Pengukuran Reporting Compliance. Jurnal Akuntansi Akrual, 6(1), 83-103.

Kuug, S. N. (2015). Factors Influencing Tax Compliance Of Small And Medium Enterprises In Ghana. Journal of Accounting Decision, 10(2).

Noviyanti. (2016). Mengukur Kesuksesan Sistem Akuntansi Instansi Basis Akrual ( Saiba ) Menggunakan Model DeLone \& McLean. Jurnal Tata Kelola E Akuntabilitas Keuangan Negara, 2(2), 151-174.

Nurhayati, \& Kusmuriyanto. (2017). Factors Affecting Taxpayers' Satisfaction of E-Billing System Users. Accounting Analysis Journal, 6(2), 148-159.

Nuridayu, Y., Rosiati, R., \& Norul Syuhada, A. H. (2017). Tax Penalties and Tax Compliance of Small Medium Enterprises (SMEs) In Malaysia. International Journal of Business, Economics and Law, 12(1), 81-91.

Oladipupo, A. O., \& Obazee, U. (2016). Tax Knowledge, Penalties and Tax Compliance in Small and Medium Scale Enterprises in Nigeria. Journal of 
Accounting and Business, 8(1), 1-9. https://doi.org/10.4236/ib.2016.81001

Prameswara, I. G. A. B. P., \& Wirasedana, I. W. P. (2018). Analisis Kesuksesan Sistem Informasi Keuangan Daerah dengan Mengadopsi Model DeLone \& McLean. E-Jurnal Akuntansi Universitas Udayana, 24(1), 196-223.

Rai, I. P. G. L., \& Suardikha, I. M. S. (2019). Analisis Kesuksesan SIPKAD Berdasarkan Model Delone \& McLean pada Sekretariat Daerah Kabupaten Buleleng. E-Jurnal Akuntansi Universitas Udayana, 29(2), 742-754.

Sari, A. N., \& Rachmanto, A. (2018). Pengaruh Kualitas Pelayanan Pajak dan Kualitas Sistem E-Filing Terhadap Kepuasan Pengguna (Wajib Pajak). Jurnal Akuntansi Fakultas Ekonomi Dan Bisnis Universitas Komputer Indonesia, 1-21.

Siahaan, S., \& Halimatusyadiah, H. (2018). Pengaruh Kesadaran Perpajakan, Sosialisasi Perpajakan, Pelayanan Fiskus, Dan Sanksi Perpajakan Terhadap Kepatuhan Wajib Pajak Orang Pribadi. Jurnal Akuntansi, 8(1), 1-13.

Solikah, M., \& Kusumaningtyas, D. (2017). Influence the Quality of the System and the Quality of the Information on E- Filing Users Satisfaction. The 3rd International Conference on Economics, Business, and Accounting Studies (ICEBAST), (188-192), 24-25.

Tam, C., \& Oliveira, T. (2016). Understanding the impact of m-banking on individual performance: DeLone \& McLean and TTF perspective. Computers in Human Behavior, 61, 233-244. https:/ / doi.org/10.1016/j.chb.2016.03.016

Uly, Y. A. (2019). Pelaporan SPT Baru 61,7\%, Tingkat Kepatuhan Wajib Pajak Rendah.https://economy.okezone.com/read/2019/04/02/20/2038285/pel aporan-spt-baru-61-7-tingkat-kepatuhan-wajib-pajak-rendah

Utomo, G. S., Titisari, K. H., \& Wijayanti, A. (2019). Pengaruh Kualitas EGovernment Terhadap Kepuasan Pengguna E-Filing. Jurnal Widya Ganeswara, 28(2), 12-23.

Veeramootoo, N., Nunkoo, R., \& Dwivedi, Y. K. (2018). What determines success of an e-government service? Validation of an integrative model of e-filing continuance usage. Government Information Quarterly, 35(2), 161-174.

Wei, K.-M., Tang, Y.-T., Kao, Y.-C., Tseng, L.-C., \& Wu, H.-H. (2017). Using an updated Delone and McLean model to assess the success of implementing the ward cleaning logistics system in a medical center. Journal of Statistics and Management Systems, 20(5), 965-976.

Wicaksono, H. N. (2016). Analisis Kesuksesan Sistem Informasi Manajemen Menggunakan Pendekatan Updated D\&M IS Succsess Model di Rumah Sakit Umum Kaliwates Jember. Artikel Ilmiah Hasil Penelitian Mahasiswa.

Wulandari, D., Setyanto, A., \& Nasiri, A. (2019). Analisis Keberhasilan Sistem Informasi Pmb Amikom Yogyakarta Dengan Metode the Updated Delone \& Mclean Is Success Model. Jurnal Intechno, 1(3), 1-5.

Zaidi, S. K. R., Henderson, C. D., \& Gupta, G. (2017). The moderating effect of culture on e-filing taxes: evidence from India. Journal of Accounting in Emerging Economies, 7(1), 134-152. 